\title{
H'stónias de opressão e censura n'O santo inquérito, de Dias Gomes
}

\section{ANDRÉ LUIS MiTIDIERI \\ Mestre e doutor emLetras pelo PPGL da PUCRS, compós-doutoramento emEstudos Literánios pela UFRGS. Professor de Literatura no Curso de Letras da Universidade Estadual de Santa Cruz (UESC) e Docente Efetivo de Literatura e História no PPGL - Mestrado emLinguagens e Representações - da mesma instituição. Docente colaborador no PPGL - Mestrado em Literatura Comparada - da Universidade Regional Integrada do Alto Unuguai e das Missões, campus Frederico Westphalen (URI-FW).}

Resumm: O santo inquérito, texto dramático de autoria dbo dramaturgo brasileiro Dias Gomes, conta a saga da cristãnova Branca Dias e sua família, perseguidbs pela Inquisição, na Paraíba do século XMII, acusados de prática de judaísmo. O texto foi escrito num período de intenso autoritarismo ecensura política. Diversas notações ealusões histónias permeiama dora literária, que aponta pera dois momentos: 1750 e 1966. Ubilizando-se principalmente do recurso da alegoria, O santo inquérito reúne passado e presente. Do passado, o terror e a opressão impetradbs pelo Tribunal do Santo Ofício emsua perseguição aos hereges. Do presente, a dominação e atrocidades exercidas pelo govemo militiar.

Pallavras-chave: Dias Gomes. O santo inquérito. Cristãos-novos. Inquisição. Ditadura militar no Brasil.

\section{Rosana Ramos Chaves}

Mestre pelo Programa de Pós-Graduação do curso de Letras da Universidade Estadual de Santa Cruz (llhéus - Bahia). Orientadores: Prof. Dr. André Lús Mitidieri e Profa. Dra. Carla Milani Damião.

Abstract: O santo inquérito, a play written by the Brazilian playwright Dias Gormes, tells the saga of Branca Dias and her farmily, who were persecuted by the Inquisition, in Paraíba in the Eighteenth Century, being accused of Judaic worship. The text wess written during a period of intense political persecution and censorship. Several remmarks and allusions permeate the literary work, concerming two historical periods: 1750 and 1966. Using mainly allegory, O Santo Inquérito brings together past and present. From the past, the terror and oppression conducted by the Court of the Holy Office in its persecution of heretics; and, latterly, the domination and atrocities carried out by the mililitary dictatorship.

Keymords: Dias Gomes. O santo inquérto. New Christians. Inquisition. Military dictatorship in Brazil. 

O Tribunal do Santo Ofício da Inquisição, em Portugal, foi o instrumento usado tanto pelas monarquias quanto pela I greja para capturar hereges e encher os cofres reais. Criado na Espanha no fim do século XV, inspirado em modelos medievais, "o Tribunal da Inquisição foi introduzido no Reino no século XVI, e sua ação estendeuse sobre todo o império" (LIPINER, 1977; CARNEIRO, 1983). Os crimes julgados pel os inquisidores eram de duas naturezas, analisa A nita Novinsky (1994). H avia os delitos contra a fé, como o judaísmo, protestantismo, críticas aos dogmas; e os contra a moral e os costumes, como bigamia, sodomia, feitiçaria. Aos crimes contra a fé, considerados mais graves do que os crimes contra os costumes e a moral, eram aplicadas penas muito mais severas. Os réus tinham quase sempre seus bens confiscados, enquanto os infratores dos costumes recebiam sentenças leves e, em raros casos, a pena de morte.

A Inquisição durou cerca de três séculos no Brasil. Apesar da caça às bruxas e a infiéis em geral, seu alvo principal foram os cristãos-novos. Esses nasceram da conversão forçada, ocorrida em 1496. O contrato matrimonial firmado entre Dom Manuel, sucessor de D. João II, e a filha dos Reis Católicos, a qual se recusava a pisar em solo onde houvesse praticantes do judaísmo, forçou 0 rei português a adotar a política de "[...] eliminação dos seguidores da Lei Velha, decretando, em 24 de dezembro de 1496, a expulsão de mouros e judeus até outubro do ano seguinte, sob pena de confisco de bens e pena de morte, ficando sua permanência condicionada à conversão à fé cristã" (VAINFAS; H ERM ANN, 2005, p. 34). Segundo José Antônio Saraiva (1994), com a conversão forçada, acabaram em Portugal os judeus e nasceram os cristãos-novos. Lá, o termo passou a designar todo indivíduo convertido à força, ou que tinha em sua linhagem, próxima ou remota, algum ascendente em tal situação. Em contraponto a esse grupo, nasceram também os cristãos-velhos.

No século XVIII, período em que se passa a história contada pelo dramaturgo Dias Gomes, descendentes dos 
batizados em pé, como também são conhecidosos cristãosnovos, já estavam em processo avançado de assimilação dentro do cristianismo, quando a perseguição inquisitorial veio aqui procurar os hereges judaizantes (SARAIVA, 1994; VAINFAS; SOUZA, 2000; M ELLO, 2009). Ou seja, mesmo sendo cristão convicto, o descendente de judeu ou cristão-novo era portador de sangue impuro, raça infecta, hereditariamente viciado. Um descendente de deicida era, em qualquer época, por mais longínqua que fosse sua ascendência judia, um herege em potencial. A ssim, para o Santo Ofício, cristão-novo e herege eram termos sinônimos (DELUM EAU, 1989).

A saga dos cristãos-novos e as perseguições impetradas pelo Santo Ofício constituem-se no pano de fundo de $O$ santo inquérito (1995). Escrita na década de 1960, a peça teve várias edições e montagens teatrais. Nessa obra literária, Dias Gomes conta que a protagonista, Branca Dias, salva o padre Bernardo de um afogamento. A partir de então, o jesuíta procura salvá-la dos perigos que, segundo ele, a cercavam. A paixonado pela jovem, tentando purificar-se das tentações da carne, padre Bernardo lança suspeitas sobre a conversão da família ao catolicismo, com base na conversão forçada do avô de Branca, pai de Simão Dias. A personagem não percebe a paixão que o jesuíta sente por ela e, considerando-se uma boa cristã, parece também não entender sua condição de cristã-nova. Denunciados pelo Santo Ofício, Simão consegue salvar-se; Augusto, noivo da protagonista, morre devido às torturas; Branca é condenada à morte, acusada de heresias.

Dias Gomes (1995) afirma que, sem dúvida, a personalidade histórica Branca Dias existiu, embora, admita ele, a história não seja tão precisa. Há divergências quanto à nacional idade dessa criptojudia, já que uns a dão por portuguesa, enquanto outros a dão por paraibana; al guns escritores, como A demar Vidal (1950), chegam a citar datas precisas para o nascimento e morte da jovem; há controvérsias quanto a seu falecimento, se por velhice 
ou queimada em fogueira; também não há consenso quanto ao lugar da sua execução, se Portugal ou Brasil.

A personagem Branca Dias foi construída por Dias Gomes após seu ingresso na Rádio Nacional, onde permaneceu até 1964. Graças à pesquisa folclórica para o programa Todos cantam sua terra, o dramaturgo teve acesso à(s) lenda(s) sobre a cristã-nova perseguida pela Inquisição. Conhecedor das diversas posições históricas e versões lendárias e, principalmente, a partir delas, afirma o escritor: "A mim, como dramaturgo, o que interessa é que Branca existiu, foi perseguidaevirou lenda. A verdade histórica, em si, no caso, é secundária; o que importa é a verdade humana e as ilações que dela podemos tirar. Se isto não aconteceu como aqui vai contado, podia ter acontecido" (GOMES, 1995, p. 13).

A personalidade histórica Branca Dias, famosa judaizante quinhentista, teve sua vida contada e representada de várias maneiras. Lipiner (1969) afirma não haver dúvidas de que Diogo Fernandes e sua esposa existiram. 0 historiador conta que, segundo denúncia tomada a 8 de outubro de 1591, soube-se que, "[...] na capitania de Pernambuco, João Dias e seu pai Manoel Dias, Branca Dias e seu marido Diogo Fernandes, vieram degredados e penitenciados pelo Santo O fício de Portugal, tendo Diogo Fernandes morrido na lei de Moisés" (LIPINER, 1969, p. 16). Contudo, o objetivo de Dias Gomes (1995) não foi documentar a vida da criptojudia quinhentista. Isto é, $O$ santo inquérito não constitui um documento histórico; a personagem foi (re)criada pelo dramaturgo a partir de lendas e das narrativas históricas sobre o sujeito real que a inspirou.

Diversas notações e alusões histórias, todavia, permeiam O santo inquérito (1995). O texto foi escrito num período de intensa perseguição e censura, no Brasil, por parte do governo militar. Dias Gomes tentou driblar o sistema. Como o governo não permitiria a encenação de uma peça que criticasse a situação atual de repressão ao povo brasileiro, o dramaturgo optou por apresentar 
${ }^{1}$ Embora Dias Gomes tenha colocado o avô da protagonista como um dos que escaparam com vida à conversão forçada, em Lisboa, isso não seria historicamente possível. A conversão em bloco se deu em 1496, enquanto a trama da obra literária se passa em 1750.

no palco o contexto de perseguição étnica, política e religiosa aos judeus e cristãos-novos no século XVIII. No texto dramático O santo inquérito (1995), Branca Dias é neta de um criptojudeu, isto é, classe de "[...] judeus que, impelidos de terror, aceitaram o batismo e tornaram-se pseudo-cristãos, vivendo como católicos, mas prestando culto no seu intimo à Lei velha" (LIPINER, 1977, p. 53). Foi essa personagem quem praticou rituais judaizantes e pediu que a neta também os praticasse, embora sem mencionar o seu teor religioso. ${ }^{1}$

Tanto Serebrenick (1962) quanto Wiznitzer (1966) são categóricos ao afirmar sobre a existência de criptojudeus no Brasil colonial. De início, sem a pressão da Inquisição, sem leis e exigências que diferenciassem cristãos-velhos de cristãos-novos, o cristianismo vivido por esses judeus convertidos à força, em suas primeiras gerações, era, por conseguinte, apenas externo. Por isso, o número de criptojudeus, nessa época, analisa também Goresntein (2005), deveria ser grande. Quanto mais próximo da conversão forçada, menos cristianismo sincero e mais criptojudaísmo seriam encontrados, tanto em Portugal quanto no Brasil. Todavia, à medida que avançamos no tempo, alguns fatores vão modificando essa identidade religiosa.

Vainfas e Souza (2000) afirmam que um primeiro fator a contribuir para 0 enfraquecimento da religião judaica teria sido a degradação do culto hebraico. A religião hebraica ortodoxa era praticada em culto público com sinagogas, livros sagrados, rabinos, regras dietéticas. Com a clandestinidade, o culto judaico perdeu o sentido religioso e passou a meros costumes domésticos praticados principalmente pelas mulheres. Outro fator importante, enfatizado por Goresntein (2005) e Saraiva (1994), foram os casamentos mistos. Os filhos resultantes dessa união eram criados na religião católica. Do século XVI, quando os judeus começaram a vir para o Brasil, até o século XVIII, esses fatores, dentre outros, contribuíram para que diminuísse o número de judaizantes. $\mathrm{A}$ assimilação teria 
sido um processo gradual, que a Inquisição interrompeu. Descendentes de judeus, distantes da conversão forçada, nem sabiam o que era judaizar, não conheciam ritos nem costumes (GOREN STEIN, 1994; VAINFA S; ASSIS, 2005). Contudo, em 1750, aos ol hos da inquisição, a protagonista Branca Dias era criptojudia.

Os costumes judaizantes estavam definidos nos Monitórios, documentos cuja leitura era feita tanto nas igrejas, a fim de orientar os delatores, quanto nas sessões do Tribunal do Santo Ofício. A M esalnquisitorial lia preceitos da lei de Moisés, perante os presos, para em seguida perguntar-Ihes se os praticaram. "Tanto a comunidade cristã-velha, como a cristã-nova, sabia perfeitamente 'como reconhecer um judaizante', seguindo as instruções dos M onitórios Inquisitoriais, desde a primeira V isitação afixados às portas das igrejas da Colônia", diz Gorenstein (1994, p. 119). De acordo com o M onitório Inquisitorial de 1570, segundo Hermann (2005), a Visitação ensinava que costumes como: guardar o sábado sem trabalhar e usando traje de festa; limpar a casa às sextas-feiras; banhar e amortal har os defuntos; cel ebrar datas judaicas e circuncidar os filhos eram práticas judaicas.

Por desconhecer quais eram os costumes judeus - fato que chama a atenção na obra literária, visto que os Monitórios Inquisitoriais tinham grande divulgação - a personagem Branca Dias não se defende de qualquer suspeita Iançada sobre si mesma e sobre sua família. Os inquisidores foram à casa de Simão Dias proceder às investigações, fazendo perguntas que visavam descobrir indícios de criptojudaísmo. A Branca Dias, perguntaram: "Come carne em dias de preceito?", "M ata gal inhas com o cutelo?", "Come toicinho, lebre, coelho, polvo, arraia, aves afogadas?", "Toma banho às sextas-feiras?", "E se enfeita?", "Quanto tempo leva enfeitando-se?" (GOM ES, 1995, p. 32). Todas essas perguntas estavam elencadas no Monitório Inquisitorial.

Durante uma conversa com o padre Bernardo, esse "avança para ela e põe-Ihe a mão sobre a cabeça, 
escorregando-a depois, lentamente, pelo rosto, como fazem os judeus para abençoar as crianças" (GOMES, 1995, p. 58). Branca ri da situação, pois tal ato lembravaIhe 0 avô. A protagonista conta que ele costumava pôr a mão em sua cabeça, escorregando-a pelo seu rosto, como agora fizera o padre. Também a levava para chupar cajus na roça, depois fazia um enorme colar com as castanhas, pendurava no pescoço de Branca e dizia que ela era mais rica do que a rainha de Sabá! A lembrança da morte do avô era acompanhada do "[...] cheiro ativo de azeitonas e um frio aqui acima do estômago. Mas nunca vou poder esquecer... Era um velho cheio de manias. Pediu que botassem uma moeda na sua boca, quando morresse" (GOM ES, 1995, p. 59). A promessa foi cumprida. Seu pai Ihe deu uma pataca, que a menina colocou sobre os lábios do avô.

A ssim, não foi difícil para o Santo Ofício, na obra literária, identificar Branca Dias como criptojudia. Além de ser neta de conversos, logo, uma herege em potencial, a personagem também "praticara" os ritos hebraicos. Soares (2001) confirma que, de fato, banhar-se às sextasfeiras, vestir roupa nova nesse dia, enfeitar-se com joias, abençoar as crianças escorregando a mão por sua cabeça, ser enterrado com uma moeda eram - e al guns ainda são, como abençoar a criança escorregando a mão por sua cabeça - costumes judeus, ainda que nem todos ligados a um judaísmo ortodoxo. Questionada por ter colocado uma moeda na boca do defunto, Branca, que não sabia do teor religioso de tal prática, responde: "Eu era uma criança... Faria tudo que me mandassem... A gora mesmo eu o faria, se al guém me pedisse!" (GOMES, 1995, p. 78). $E$ apenas no julgamento a personagem fica sabendo que escorregar a mão pelo rosto, como fizera seu avô, era uma bênção judaica.

Para o Tribunal, herege e judeu eram sinônimos, por isso, de nada adiantou à personagem afirmar ser "[...] uma boa moça, cristã, temente a Deus. Meu pai me ensinou a doutrina e eu procuro segui-la" (GOMES, 
1995, p.33). 0 chamado "Estatutos de Pureza de Sangue" consistia numa legislação de origem econômica e racista, nas palavras de Carneiro (1983). Esse documento deixava claro que os cristãos-novos não eram iguais aos cristãosvelhos, independentemente de quanto tempo houvesse transcorrido desde a conversão forçada ou não de um ancestral distante. Ainda que cristãos há mais de dois séculos, os cristãos-novos eram perseguidos por terem sangue judeu, mesmo que fossem católicos sinceros (GORENSTEIN, 1994; M ELLO, 2009; NOVINSKY, 1994; SARAIV A, 1994).

Branca Dias conta ainda ao padre Bernardo que insistiu para que seu pai a deixasse aprender a ler e escrever, a ponto de quase brigarem. 0 direito à leitura Ihe parecia tão natural que era difícil entender por que ela não poderia ler. Uma cena na peça chama a atenção, em relação ao perigo da leitura. Durante a visita dos inquisidores à casa de Simão e Branca, para "investigar" se eles são de fato cristãos, o N otário encontra al guns livros, e age "[...] como se encontrasse uma bomba: Livros!". Ao exclamar que são "M eus livros! São meus! Que vai fazer com eles?", Branca deixa os inquisidores surpresos: "Sabe ler?" (GOMES, 1995, p. 64).

0 problema vai se agravar, pois todos os livros encontrados pelo Notário são proibidos pela I greja. Inclusive a Bíblia em língua vernácula. A fala de Simão Dias é crucial: "Eu bem Ihe disse... eu bem que me opus sempre... Esses livros - para quê? [...] Que ganhamos com isso? Estamos agora marcados" (GOM ES, 1995, p. 65). 0 saber ler não é a única surpresa que a personagem causa nos inquisidores. Mais do que isso, 0 acesso à leitura e aos títulos proibidos tornam-se um grande problema. Novinsky (1994) registra que, durante todo o período de censura imposta pelo Santo Ofício, muitos livros fizeram parte do Índex, leituras proibidas pela Igreja. No M onitório do Inquisidor Geral constavam dois itens sobre o assunto: "um dedicado aos livros proibidos em geral, e outro à 'bíblia em linguagem'" (LIPINER, 1969, p. 107). 
Todo livro que supostamente abordasse "coisas lascivas e desonestas, livros sobre feitiçarias, astrologia, assim como qualquer escrito contra a Santa Fé Católica e os bons costumes" (NOVINSKY, 1994, p. 53) deveria ser apreendido. 0 destaque para o perigo da leitura da Bíblia em linguagem corrente era enorme. Muitos colonos brasileiros foram denunciados por possuírem tal livro. 0 cuidado era para garantir que o povo recebesse a mensagem do Evangel ho apenas através de interpretações do clero. A censura a livros, portanto, era um ponto altamente importante para a Igreja (DELUM EAU, 1989, LIPINER, 1969).

Sobre 0 assunto, em seu conhecido livro 0 queijo e os vermes, publicado originalmente em 1976, o historiador Carlo Ginzburg retrata o cotidiano do moleiro Domenico Scandella, torturado e acusado de heresia pela Inquisição. Tal reconstituição histórica, que envolve 0 problema da leitura, nos ajuda a entender a gravidade dos atos da personagem Branca Dias. Por sua vez, outro historiador, Elias Lipiner, em O sapateiro de Trancoso \& o alfaiate de Setubal (1993), narra a saga de Gonçalo Anes, de alcunha Bandarra, autor de trovas alegóricas e proféticas, no século XVI. Embora não se tenha provado se ele era cristão-novo ou não, seus textos eram lidos por muitos cristãos-novos e também por cristãos-velhos que, a partir deles, alimentavam suas esperanças messiânicas e sebastianistas. Suas trovas proféticas apoiavam-se em textos do Antigo Testamento e "[...] a crença dos cristãosnovos era alimentada pelas metáforas, imagens e figuras bíblicas, tão apreciadas por eles, de que lançara mão 0 sapateiro para compor suas trovas e fundamentar suas predições" (LI PINER, 1993, p. 43).

A Igreja mandou que o sapateiro de Trancoso parasse de escrever suas trovas. Contudo, a essa altura, a escrita do sapateiro já havia se espalhado, servindo também de base para que Luis Dias, cristão-novo confesso, morador da vila de Setubal, conhecido como 0 alfaiate de Setubal, "[...] fosse considerado por alguns 
entusiastas como o próprio M essias" (LIPINER, 1993, p. 52) anunciado por Bandarra, o profeta. A influência dos escritos do sapateiro de Trancoso também nos dá uma ideia da dimensão, da força da leitura, das novas ideias que podem vir através dos livros. Daí o controle rígido exercido pelo Santo Ofício.

No texto de Dias Gomes, Branca Dias é condenada porque lê, pensa, fala o que as autoridades não permitem. Embora não seja seu desejo, ao contrário da personalidade histórica que, segundo Lipiner (1969) conservou conscientemente os hábitos judaicos, a protagonista quebra as leis impostas pelo governo da época. 0 sistema inquisitorial, que era o poder político de 1750, no Brasil, puniu mais do que uma etnia, o ser humano que buscava liberdade.

Desse modo, a representação literária extrapola a problemática judaica daquele período da história lusobrasileira. A perseguição e execução da protagonista, a prisão, tortura e morte de Augusto, a omissão de Simão Dias, o poder político-religioso do Santo Ofício, com seus representantes, fizeram um paralelo entre dois momentos: 1750 e 1966. O santo inquérito (1995) conseguiu transpor os mais de 200 anos que separavam as duas épocas. Do passado, mostrava o terror e a opressão impetrados pelo Tribunal do Santo Ofício. Do presente, a dominação exercida pelo governo militar, marcado por violentos conflitos político-ideológicos.

Em entrevista concedida a Edgard Ribeiro de A morim, Um teatrólogo na TV, Dias Gomes (GOMES apudAM ORIM , s/p, s/a) relatou que, à sua geração "[...] restaram duas opções: ou você se adaptava ao regime e não questionava nada ou partia para um texto de metáforas, caminho que alguns autores encontraram para continuar resistindo e denunciando". O cuidado não era à toa, afinal, foram mais de 300 peças censuradas a partir da década de 60 . A ssim como outros escritores de sua geração, o dramaturgo decidiu não se calar. Para tanto, através do Teatro de Resistência, eles contestaram 
a realidade brasileira, utilizando, principalmente, o recurso al egórico.

Gagnebin (1994) comenta que a prática de aprender uma outra leitura que busque sob as palavras do discurso seu verdadeiro pensamento era chamada pelos Estóicos de hypo-noia, isto é, subpensamento. Por suavez, a palavra al egoria, que vem do grego allo, outro e agorein, dizer, é definida como um discurso que faz entender outro, numa linguagem que oculta outra, podendo ainda ser considerada como alegoria "toda concretização, por meio de imagens, figuras e pessoas, ideias, qualidades ou entidades abstratas" (M OISÉS, 1985, p. 515). Portanto, outro discurso, numa linguagem que oculta outra.

Para Fonseca (1997), a reabilitação, ou revalorização da alegoria, feita por W alter Benjamin, no século XX, tornou-se o fundamento de todaa estéticadesse, não se limitando - a alegoria - "[...] à condição de figura ocasional da retórica, mas, ao lado do símbolo, à de figura fundamental da estética literária" (FONSECA, 1997, p. 59). Gagnebin (1994), por sua vez, comenta que a alegoria "[...] ressalta a impossibilidade de um sentido eterno, insiste na sua não-identidade essencial e na necessidade de perseverar a temporalidade e a historicidade para construir significações transitórias" (p. 45). Portanto, ao dizer outra coisa (allo-agorein) transpondo aquilo que visava, a alegoria indica que não há mais o sentido único, visto que sempre surgem sentidos novos. Logo, esse recurso desvela a ausência do sentido verdadeiro, da totalidade verdadeira, da totalidade histórica.

0 agora escondido no passado é para o que apontaa alegoria, afinal, ela "[...] permite decifrar os significados em seu devir, momento a momento, na busca da restauração da continuidade em momentos heterogêneos", comenta Fonseca (1997, p. 102). 0 presente escondido no passado permite dizer aquilo que o poder não permite ser dito, e assim pensou Dias Gomes, valendo-se desse recurso que Ihe permite travar um diálogo entre o texto no contexto e o contexto no texto, comenta Kothe (1986). Por exemplo, 
em O santo inquérito, o contexto no texto é 1750, quando - Brasil estava sob o domínio da Santa Inquisição; o texto no contexto, por sua vez, está ligado a 1966, quando o Brasil estava sob o domínio dos militares, embora se refira diretamente a 1750, época em que vivia a personagem.

$\mathrm{Na}$ teoria da modernidade de $\mathrm{W}$ alter Benjamin, comenta Gagnebin (1994), a alegoria consiste em um recurso que diz respeito à reunião do passado e do presente: por isso, é possível reunir histórias diferentes diferentes gerações - por seu intermédio e fazer falar tanto o passado como o presente. 0 que ocorreu com a famosa criptojudia do século XVI e com a personagem Branca Dias, no passado, "fala alto" em um presente marcado por injustiças sociais e políticas. A alegoria, portanto, se associa à história "disfarçada" de ficção. Dias Gomes quis falar do presente, todavia, isso não se mostrou possível devido à censura imposta pelas autoridades, assim, procurou no passado uma situação ou acontecimento que valesse no presente como verdade. ${ }^{2}$

O dramaturgo, portanto, foi mais um dos que venceram a opressão e falaram, de modo alegórico, o que estava impossibilitado de ser dito de modo direto. 0 uso da linguagem al egórica, no contexto da ditadura militar, constituiu-se, pois, numa peça-chave dentro da luta contra o sistema graças à sua al usão a novos sentidos, às releituras e reinterpretações históricas possibilitadas. Se a alegoria permitiria justapor passado e presente, 1750 e 1966, a perseguição e morte de Branca Dias, subjugada pelo Santo Inquérito, tornaram-se a perseguição e morte de tantos brasileiros, subjugados pelos militares. Ou seja, em qualquer lugar onde houver um poder tirano, sempre existirão vítimas como Branca Dias e Augusto. A ficção se aliou à História “disfarçada” de ficção.

Dias Gomes (1995) lembra que as razões apresentadas em defesa do Tribunal do Santo O fício são as mesmas de todos os opressores. "São as mesmas de H itler, de Franco e de M acCarthy", diz ele (p. 10). As palavras do padre Bernardo, na cena de abertura da peça, e do
${ }^{2}$ Essa união é o que se reconhece como "imagem dialética" em Benjamin. 
visitador, durante o julgamento, exemplificam o discurso atemporal das autoridades: "[...] quem tem 0 direito de mandar tem também o direito de punir [...] Devemos deixar que continue a propagar heresias, perturbando a ordem pública e semeando os germes da anarquia, minando os alicerces da civilização que construímos, a civilização cristã?" (GOM ES, 1995, p. 31). E ainda:

\begin{abstract}
VISITADOR - A Igreja, Branca, a sua Igreja, está diante de um perigo crescente e ameaçador. Toda a sociedade humana, a ordem civil e religiosa, construída com imensos esforços, toda a civilização e cultura do Ocidente, estão ameaçados de dissolução.

BRANCA - E sou eu, senhor, sou eu a causa de tanta desgraça?!

VISITADOR - Não é você, isoladamente; são milhares que, como você, consciente ou inconscientemente, propagam doutrinas revolucionárias e práticas subversivas. Está aí o protestantismo, minando os alicerces da religião de Cristo. Estão aí os cristãos-novos, judeus falsamente convertidos, mas secretamente seguindo os cultos e a lei de Moisés (GOMES, 1995, p. 76).
\end{abstract}

Da fala das autoridades de 1750, destacamos termos como anarquia, doutrinas revolucionárias, práticas subversivas, ordem pública, palavras muito mais próximas da linguagem do século $X X$ do que da linguagem do século XVIII. O próprio discurso do padre Bernardo, de que "[...] quem tem o direito de mandar tem também o direito de punir", segundo comentário de Dias Gomes, repete o discurso de São Tomás de Aquino. A citação utilizada pelo dramaturgo foi: "Conforme São Tomás, todo aquele que tem o direito de mandar, tem também 0 de punir, e a autoridade que tem o poder de fazer leis tem também o de Ihes dar a sanção conveniente" (GOMES, 1995, p. 14). Perturbar a ordem pública e semear os germes da anarquia, para os opressores - embora com outra linguagem - é o mesmo que discordar das verdades 
impostas pelas autoridades, e "[...] aqueles que trazem em si a verdade têm o dever sagrado de estendê-la a todos, eliminando os que querem subvertê-la" (GOMES, 1995, p. 31). Ainda que os meios para "eliminar" os discordantes variem em cada época, a essência, o princípio continua o mesmo. A Inquisição em si, seu aparato, sua finalidade, não constituía novidade em 1750, pois, na I dade M édia, 0 sistema inquisitorial já era atuante.

A intolerância pode ser encontrada nas duas épocas: 1750 e 1966. Para Branca Dias e sua família, pesou o "sangue infecto", a origem cristã-nova do avô. A intolerância religiosa aponta para a intolerância política, pois o criptojudeu vivia o judaísmo clandestinamente, escondido do poder público que não tolerava tal prática. Como não seguia a "ordem" estabelecida pelas autoridades, deveria ser reprimido, eliminado. Nas palavras do Visitador: "Estão aí os cristãos-novos, judeus falsamente convertidos, mas secretamente seguindo os cultos e a lei de Moisés" (GOM ES, 1995, p. 76), pessoas que minavam a religião de Cristo, ameaçando a ordem civil com suas práticas revolucionárias e subversivas. Branca Dias tornou-se um "elemento subversivo" que, por discordar da ideologia vigente, recebeu a pena de morte como sentença.

O Santo Ofício encontrou, principalmente nos cristãos-novos, osheregesqueprocurava. 0 governo militar também transformou muitos brasileiros em subversivos e, logo, inimigos. Desejo de liberdade foi entendido como anarquia, ao mesmo tempo em que a sentença defendida pela Inquisição também era defendida pel os militares, pós 64. Segundo Cerqueira (2007), o julgamento de Branca aponta para os inquéritos policiais militares. 0 governo dizia que estava defendendo o Brasil contra o comunismo ateu e, por isso, prendia os subversivos - os hereges - que desejavam destruir o país, ao lado dos comunistas. I sso não aconteceu apenas no Brasil. Em determinado momento de sua história, os Estados Unidos "[...] julgaram necessário proteger-se contra a desintegração da sua sociedade. 
Começaram a citar diante dos tribunais os comunistas declarados [...] este proceder contra os comunistas é uma genuína restauração dos princípios inquisitoriais da Idade M édia" (GOM ES 1995, p. 15).

A Inquisição dizia fazer tudo em nome de Deus e os militares reiteravam que o objetivo de suas ações, principalmente as viol entas, era manter a democracia. A protagonista, a princípio, deveria ser salva, afinal, ela era "um dos tesouros do Senhor" (GOMES, 1995, p. 39), segundo o padre Bernardo. Todavia, ao continuar discordando do jesuíta e da I greja, do poder da época, ele teve que puni-la. Toda heresia, ou toda discordância, deveria ser eliminada, ainda mais vinda de pessoas ingênuas:

PADRE - o Diabo está a todo o momento a nos rondar os passos, a se insinuar e a se infiltrar. $E$ é principalmente os ingênuos, os sem-maldade, como você, que ele escolhe para seus agentes [...] Satanás escolhe os bons, os inocentes, os puros, porque são eles muito úteis e insuspeitos na propagação de suas ideias. Repare que as grandes heresias surgem sempre de pessoas que pretendem salvar a humanidade. (GOMES 1995, p. 43).

Para o jesuíta, Branca era alguém na "mira do diabo" e, como tal, poderia insinuar-se, infiltrar-se, propagar suas ideias sem levantar suspeitas. A bondade, inocência e pureza fariam dela um agente de Satanás. A protagonista tinha acesso à informação, sabia ler e possuía livros, discutia diversos assuntos com seu noivo. Augusto também era um rapaz esclarecido para a época; foi quem deu a ela uma Bíblia em linguagem vernácula. Diferente da protagonista, que só tomou consciência de sua situação perante o Tribunal do Santo Ofício, ao fim do jul gamento, o rapaz questionava, discordava, posicionavase criticamente diante dos desmandos das autoridades.

Cristão-velho, Augusto aceitava o degredo, mas não a fal ta de respeito ao ser humano. Sobre um degredado, 
disse: "Eu estava no Recife e o vi passar, com o baraço no pescoço, tangido como um cão, entre insultos e pedradas de uma multidão que ria e incentivava a violência. $\mathrm{E}$ nunca esquecerei o seu olhar. Parecia dizer: 'Isto que aqui vai, é um homem. Um ser feito à semelhança de Deus"' (GOMES, 1995, p. 39). E ainda, refletindo sobre o Santo Ofício: “[...] em nome da Igreja, do próprio Deus, às vezes cometem-se atos que Ele jamais aprovaria. Em nome de um Deus-misericórdia, praticam-se vinganças torpes, em nome de um Deus-amor, pregam-se o ódio e a violência" (GOMES, 1995, p. 40). Para o noivo de Branca, o rosário era usado a fim de cobrir toda sorte de interesses que nada tinha a ver com Deus.

Augusto encaixava-se na definição do jesuíta, de que as grandes heresias vêm de pessoas que desejam salvar o mundo. Portanto, precisava ser calado para não influenciar outros jovens com suas ideias revolucionárias. Esse foi também o discurso do governo militar, tanto que professores, pesquisadores, jornalistas, intelectuais, acabaram presos em função das "heresias" que poderiam disseminar. Na época militar, a censura bloqueava a circulação de determinadas informações, muitos livros, como os de Branca Dias, al imentaram fogueiras. Augusto Coutinho seria o equivalente do "intelectual engajado", comenta Cerqueira (2007). A I greja se preocupava com a influência que ele exercia sobre Branca, e sobre as pessoas de modo geral, pois ele "[...] conhece as leis dos homens, que não se podem sobrepor às leis de Deus. M as ele pensa que sim [...] soube de certas atitudes de rebeldia desse rapaz" (GOM ES 1995, p. 47).

Cerqueira (2007, p. 164) anota que, para o regime militar, os jovens estavam mais vulneráveis a "[...] se deixarem ludibriar pelo inimigo. As estatísticas mostram que $38,9 \%$ dosqueforam processadospela ditaduratinham idade igual ou inferior a 25 anos, ou seja, 2.868 jovens, sendo que dentre estes, 91 ainda não haviam atingido 18 anos". A ugusto morreu devido às "ideias heréticas", antes mesmo de Branca. Os inquisidores tinham informações 
pertinentes a ele, sua "rebeldia", seus estudos na capital da metrópole, sua postura sobre a lei dos homens e a de Deus, principalmente acerca de sua influência sobre outros jovens. A preocupação da Inquisição, portanto, pode ser comparada à dos militares.

Também nas duas épocas, a confissão era obtida por meio de torturas. Branca sofreu tortura psicológica e seu noivo, torturas psicológica e física. Ao ser trazido à presença do Visitador, segundo a rubrica do texto, 0 aspecto de Augusto é deplorável. M esmo ameaçado de excomunhão, o rapaz diz desejar ter a fibra dos primeiros cristãos para resistir às torturas. 0 Visitador fala desse procedimento usado pelos inquisidores, e também pela ditadura militar. Diz ter ordenado a tortura devido à obstinação do próprio Augusto em esconder a verdade, e ao ouvir que torturaram o rapaz por "apenas" 15 minutos, lembra ao Guarda que "[...] o limite máximo permitido pelas normas do processo é uma hora" (GOMES, 1995, p. 84). 0 Guarda, com tranquilidade, comenta que parou a tortura porque rapaz desmaiou. A o ouvir a recomendação para obter a verdade sem cometer excessos, o Guarda e 0 Notário retrucam:

GUARDA - Mas a culpa foi dele, senhor. Ele assinou a declaração.

NOTÁRIO - É verdade, antes de ter início a tortura, ele assinou a declaração de praxe. Tenho-a aqui. (Mostra um papel, que lê, depois de engrolar algumas palavras) '... e declaro que se nestes tormentos morrer, quebrar algum membro, perder algum sentido, a culpa será toda minha e não dos senhores inquisidores. A ssinado: Augusto Coutinho'.

GUARDA - Já veem os senhores que a culpa é toda dele. (Volta ao seu posto) (GOM ES, 1995, p. 84-5).

A penas falando 0 que 0 Tribunal queria ouvir, Augusto conseguiria salvar sua noiva, levando-a "reconhecer os próprios erros e arrepender-se" (GOMES, 
1995, p. 85), mas preferiu resistir às torturas a cometer falsa denúncia contra Branca. Sua postura marcada pela manutenção da dignidade e de suas convicções fez aflorar a consciência da própria dignidadeem Branca. Para ele, "A dor física não é tanta. Dói mais o aviltamento" (GOMES, 1995, p. 88). A lém de apontar as torturas impetradas pelos opressores e as "verdades" por el es criadas, e de denunciar as falsas acusações, obtidas através da violência, Dias Gomes também afirma em seu texto que cada pessoa pode não se corromper, ainda que isso lhe custe a vida. Exemplo disso, Augusto morreu depois de duas seções de tortura e seu sofrimento foi assistido por Simão Dias.

Simão fez o que era comum, na época da Inquisição, e o que muitos fizeram durante a ditadura militar brasileira. Segundo Saraiva (1994), muitos cristãos-novos, sob coação, sequestro dos bens, torturas no potro e na polés, falavam tudo o que os inquisidores quisessem ouvir. As denúncias não eram claras, não se dizia o nome do denunciante, o réu tinha que se defender de uma acusação desconhecida por el e. A ssim, cada pessoa trazida à M esa Inquisitorial aportava novas denúncias, e mais pessoas iam presas (N OVINSKY, 1994). Os métodos utilizados nos interrogatórios pel os militares não diferiam muito, visto que os policiais obtinham confissões por meio de coação e tortura, aplicadas durante os inquéritos. Tanto o sistema inquisitorial quanto o militar instigavam a denúncia entre parentes, recebiam delações anônimas e diminuíam o número de testemunhas. Quem se encontrasse ao lado da pessoa investigada, geralmente, era atingido (CERQUEIRA, 2007).

As personagens chamadas de Guarda e Notário, na obra literária em estudo, são emblemáticas dentro do sistema inquisitorial e apontam para dois tipos de pessoas que trabal havam para os militares. 0 Notário age como um autômato, diante do Visitador. A o longo do processo, “[...] ele se transforma na peça de uma máquina e jamais Ihe passaria ela mente emperrar deliberadamente essa engrenagem" (GOMES, 1995, p. 17). À medida que
${ }^{3} 0$ Potro era "[...] uma espécie de cama de ripas onde, ligado o paciente com diferentes voltas de corda nas pernas e braços, se apertavam aquelas com um arrocho, cortando-Ihe as carnes [...] A Polé consistia em moitão seguro no teto, onde era suspensa a vítima, com pesos aos pés, deixando-a cair em brusco arranco sem tocar no chão" (LIPINER, 1977, p 113). 
percebe como Branca não compreende o desenrolar do processo a que está submetida, sua formalidade e inexorabilidade, o Notário irrita-se porque a protagonista não coopera. Embora tal irritação seja uma prova de sua humanidade, não chega a conscientizá-lo.

À saída de Augusto da sala do julgamento, o Guarda, que não se apresenta como um autômato, para e se justifica com Branca: "Não fui eu que botei ele no potro [...], na cama com ripas. Só levei ele até lá e fiquei olhando. Sou obrigado" (GOMES, 1995, p. 90-1). A obrigação al egada pela personagem revela ter consciência do papel que desempenha, mas não a ponto de se sentir culpado ou colaborador do sistema. Para ele, se A ugusto desmaiou no período de tortura, a culpa é do próprio rapaz, que assinou a "declaração", assumindo inteira responsabilidade por qual quer osso quebrado, perda de sentido e mesmo morte durante esses tormentos.

Desde antes do julgamento, o Guarda demonstrouse certo da impossibilidade de modificar seu papel no sistema. Sem saber os motivos pelos quais a protagonista fora presa, ele diz: "Por que eu devia saber? [...] Os denunciantes denunciam, os juízes julgam, os guardas prendem, somente. 0 mundo é feito assim. E deve ser assim, para que haja ordem [...] Se não está certo, não me cabe a culpa. Sou guarda. E não foram os guardas que fizeram o mundo" (GOMES, 1995, p. 67-68). Essa fala demonstra que a personagem se isenta de tudo o que está acontecendo; o mundo pode até estar errado, mas como os guardas apenas cumprem ordens, prendem a mando de al guém, a cul pa se transfere a outra pessoa: à que manda prender, ou à que denuncia.

Simão Dias, que também presenciou a morte de Augusto, preferindo salvar sua vida e bens, disse aos inquisidores o que eles queriam ouvir, vendeu sua dignidade, calou-se diante das torturas sofridas pelo noivo de sua filha, portanto, foi cúmplice do sistema. $\mathrm{O}$ Guarda, ainda que não pelos mesmos motivos, achou-se incapaz de lutar contra os opressores, e ao calar, também 
colaborou com os opressores. Dessa forma, no ano de 1966, Dias Gomes chamava o publico à reflexão, mostrando que muitos funcionários, por se verem como incapazes de modificar a situação vigente, continuavam a realizar seu "trabal ho", colaborando com os militares.

É assim que, findo o julgamento, o Guarda vem buscar Branca para levá-la à fogueira. Ela pergunta: "É você...?", ao que o funcionário responde: "Que posso fazer?...". "Eu sei, você nada pode fazer. (Referindo-se à plateia.) Eles também acham que nada podem fazer e que nada disso Ihes diz respeito", responde a protagonista (GOMES, 1966, p. 150). Enquanto a atitude do Guarda revela omissão, conformismo, a de Branca é uma chamada para que as pessoas enfrentem as barbáries. Em qualquer situação na qual os direitos humanos fossem/sejam desrespeitados, portanto, cada pessoa poderia agir como Simão Dias, o Guarda, o Notário, ou A ugusto e Branca.

O dramaturgo desejava que o público tivesse, nessas duas últimas personagens, exemplos de atitudes que poderiam ser tomadas para enfrentar a dura realidade vivida durante o tempo de escrita de seu texto dramático. Como lembra Cerqueira (2007, p. 170), "Branca não foi morta apenas pela Igreja, mas por todo um sistema intransigente que, por meio de uma sociedade injusta, hostil e repressora é capaz de desintegrar valores humanos imprescindíveis como a integridade e a dignidade". A punição por ela recebida deveu-se ao fato de ser cristãnova, logo, uma herege em potencial, por despertar um sentimento no padre Bernardo, por ter livros, ser leitora, por conceber Deus, a vida, o mundo, a humanidade de modo diferente daquele estabelecido pelas autoridades, por expor suas opiniões, pensar por si mesma, dispensar a "ajuda" da I greja, por acreditar nas boas intenções de seus governantes, na justiça que pregavam.

A sinceridade de Branca Dias frente à astúcia dos inquisidores levou-a a uma morte trágica, emoldurada contextual mente na Inquisição portuguesa e no período colonial . Do mesmo modo, o desejo de liberdade de tantos 
jovens conduziu-os à morte sob o poder das autoridades militares brasileiras nos "anos de chumbo" cujo peso ainda se faz sentir em nosso país. As analogias ora desvendadas, ao termos o procedimento alegórico como escopo privilegiado de análise, permite-nos dizer que $O$ santo inquérito se destina a alertar a todos sobre os perigos que espreitam a liberdade da consciência dos seres humanos, independentemente de suas nacionalidades, dos tempos ou dos espaços nos quais vivem. 


\section{Referências}

AM ORIM, Edgard Ribeiro de. Um teatrólogo na TV.

Disponível em: বttp://www.centrocultural.sp.gov.br/linha/ idart\%205/televiso.htm>. A cesso em 17 jan. 2012.

CARNeI RO, M aria Luiza Tucci. Preconceito racial no Brasil colônia: os cristãos-novos. São Paulo: Brasiliense, 1983.

CERQUEIRA, P. C. B. F. F. Denunciaçôes e confissôes em ritos de alteridade: $O$ santo inquérito de Dias Gomes. Feira de Santana, 2007. 187 p. Dissertação (M estrado em Letras e A rtes). Programa de Pós- graduação em Literatura e Diversidade Cultural. Universidade Estadual de Feira de Santana. Disponível em: \http://tede.uefs.br/tedesimplificado/ tde_arquivos/1/TDE-2008-02-25T072950Z-38/Publico/ DENUNCIACOES\%20E\%20CONFISSOES\%20EM \% 20 RITOS\%20DE\%20ALTERIDADE_\%200\%20SANTO\%20IN. pdf > A cesso em 10 fev. 2011.

DELUM EAU, Jean. História do medo no ocidente: 1300-1800, uma cidade sitiada. Tradução M aria Lucia M achado, tradução das notas H eloisa Jahn. São Paulo: Companhia das Letras, 1989.

FONSECA, Orlando. Na vertigem da alegoria: militância poética de Ferreira Gullar. Santa M aria: EdUFSM, 1997.

GA GNEBIN, Jeanne M arie. História e narração em Walter Benjamin. Sao Paulo: Perspectiva; Campinas: FA PESP, 1994. (Colecao estudos: 142).

GINZBURG, Carlo. O queijo e os vermes. 0 cotidiano e as ideias de um moleiro perseguido pela Inquisição. São Paulo: Companhia das Letras, 1987.

GOM ES, Dias. O santo inquérito. Rio de Janeiro: Civilização Brasileira, 1966. 
GOMES, Dias. O santo inquérito. Rio de Janeiro: Ediouro, 1995.

GORENSTEIN, Lina. Um Brasil subterrâneo: cristãos-novos no século XVIII. In: GRINBERG, Keila (Org). Os judeus no Brasit. Inquisição, imigração e identidade. Rio de Janeiro: Civilização Brasileira, 2005, p. 137-160.

GORENSTEIN, Lina. Heréticos e impuros. a Inquisição e os cristãos-novos no Rio de Janeiro no século XVIII. Rio de Janeiro, RJ: Coleção Biblioteca Carioca - Secretaria M unicipal de Cultura do Rio de Janeiro, 1994.

HERM ANN, Jacqueline. As metamorfoses da espera: messianismo judaico, cristãos-novos e sebastianismo no Brasil colonial. In: GRINBERG, Keila (Org). Os judeus no Brasil. Inquisição, imigração e identidade. Rio de Janeiro: Civilização Brasileira, 2005, p. 87-112.

KOTHE, Flavio René. $A$ alegoria. São Paulo: Ática, 1986.

LIPINER, Elias. O sapateiro de Trancoso \& o alfaiate de Setubal. Rio de Janeiro: I mago, 1993.

LIPINER, Elias. Santa Inquisicao: terror e linguagem. Rio de Janeiro: Documentário, 1977.

LIPINER, Elias. Os judaizantes nas capitanias de cima. São Paulo: Brasiliense, 1969.

M ELLO, Evaldo Cabral de. O nome e o sangue: uma parábola genealógica no Pernambuco colonial. São Paulo: Companhia das Letras, 2009.

M OISÉS, M assaud. Dicionário de termos literários. São Paulo: Cultrix, 1985.

NOVINSKY, A nita. A Inquisição. São Paulo: Brasiliense, 1994. 
SA RAIV A, José A ntônio. Inquisição e cristãos-novos. Lisboa: Estampa, 1994.

SEREBRENICK, Salomão. Quatro séculos de vida judaica no Brasil. In:______; LIPINER, Elias (Orgs). Breve história dos judeus no Brasil. Rio de Janeiro: Biblos, 1962. p. 9-104.

SOARES, Rita Miranda. A Influência dos judeus "cristãosnovos" na cultura mineira, 2001. Disponível em «ttp://www. ensinandodesiao.org.br/A bradjin/0701.htm $>$. Acesso em 23 jul. 2010.

VAINFAS, Ronaldo; ASSIS, Ângelo A. F. A esnoga da Bahia: cristãos-novos e criptojudaísmo no Brasil quinhentista. In: GRIN BERG, Keila (Org). Os judeus no Brasil. Inquisição, imigração e identidade. Rio de Janeiro: Civilização Brasileira, 2005, p. 43-64.

VAINFAS, Ronaldo; HER M ANN, Jacqueline. Judeuse conversos na I béria no século XV: sefardismo, heresia, messianismo. In: GRINBERG, Keila (Org). Os judeus no Brasil. Inquisição, imigração e identidade. Rio de Janeiro: Civilização Brasileira, 2005. p. 15-42.

VAINFAS, Ronaldo; SOUZA, Juliana Beatriz de. Brasil de todos os santos. Rio de Janeiro: Jorge Zahar, 2000. Série Descobrindo o Brasil.

VIDAL, A demar. Lendas e superstiçôes. contos populares brasileiros. Rio de Janeiro: O Cruzeiro, 1950.

W IZNITZER, Arnold. Os judeus no Brasil colonial. São Paulo: Pioneira, 1966.

[Recebido em 30 de julho de 2012

e aceito para publicação em 29 de agosto de 2012] 